\title{
Heterosis Studies in Bread Wheat (Triticum aestivium L.) under High Temperature Stress Environment
}

\author{
Guman Singh*, Dhirendra Singh, D. K. Gothwal, Naresh Parashar and Ravi Kumar \\ Department of Plant Breeding and Genetics, \\ S.K.N. Agriculture University, Jobner, Jaipur-303329, India \\ *Corresponding author
}

\section{Keywords \\ Wheat, Heterosis, Heterobeltiosis, High temperature stress}

\section{Article Info}

Accepted:

20 May 2020

Available Online:

10 June 2020

\section{A B S T R A C T}

The present investigation was carried out to estimate relative heterosis and heterobeltiosis in wheat genotypes to identify desirable cross combinations under high temperature stress for days to heading, grain filling duration, days to maturity, plant height, number of tillers per plant, flag leaf area, number of grains per spike, peduncle length, spike length, 1000-grain weight, biological yield per plant, grain yield per plant and harvest index. The $F_{1}$ crosses were made in half diallel fashion using 10 genotypes. The experiment was conducted in randomized block design with three replications during rabi 2016-17. The results revealed sufficient degree of heterosis and heterobeltiosis for all the characters studied. An overall evaluation of heterosis for grain yield per plant across the environments revealed that the maximum heterosis over mid-parent was observed as $34.22 \%$ (Raj 3765xRaj 3777) in high temperature stress environment. Similarly, maximum heterosis over better parent was observed as $33.15 \%$ (Raj 3765xRaj 3777) in high temperature stress. Therefore, these crosses were observed more heterotic for grain yield per plant under high temperature environmental conditions. Therefore, it could be concluded that these cross combinations may be exploited in future breeding programme for the development of good heterotic gene pool of wheat for improving grain yield and other contributing traits under heat stress environment.

\section{Introduction}

Bread wheat (Triticum aestivum) is the most important food grain crop among the cereals and stands next to rice in India. It is one of the ancient grain crop consumed as primary food by human beings since the dawn of civilization and is known as the protector of man from hunger. It is a self-pollinated crop belonging to the family Poaceae. It is a hexaploid species $(2 n=6 x=42$ : AABBDD genomes) with 21 pairs of chromosome. It significantly contributed towards the success of the "Green Revolution" and has greatly helped to transform our country from a situation of ship to mouth to become a self sufficient.

In world, it is grown in about 215.44 million hectares area with the production of 731.7 
million tonnes with an average productivity of $3490 \mathrm{~kg} /$ hectare (Anonymous, 2019). The major wheat growing regions in the world are Europe, Russia, North and South America, Australia and China.

Area and production of wheat in India during year 2018-19 was recorded 29.8 million hectare and 101.2 million tonnes, respectively with an average productivity of 3390 $\mathrm{kg} / \mathrm{hectare}$ (Anonymous, 2019). In India, Uttar Pradesh has registered the highest production (30.24 million tonnes), followed by Punjab (17.04 million tonnes), Madhya Pradesh (13.93 million tonnes), Haryana (11.80 million tonnes), Rajasthan (11.20 million tonnes) and Bihar (5.08 million tonnes). These top six states together contributed around 90 per cent of the total wheat production in the country.

Wheat crop grown in Northern India under late sown condition get exposed to very low temperature upto booting stage and at later stages it has to face warm temperature that leads to forced maturity under high temperature conditions leading to poor grain yield. As a result the reproductive (spike initiation to anthesis) and ripening (anthesis to maturity) growth phases of late sown wheat crop is generally exposed to high temperature stress during the month of March to April where temperature remains around $35-40^{\circ} \mathrm{C}$. Each genotype within a plant species needs an optimum temperature range for growth at different stages such as $20-25^{\circ} \mathrm{C}$ for germination, $16-20^{\circ} \mathrm{C}$ for tillering and 20 $23^{\circ} \mathrm{C}$ for grain formation in case of wheat. Wheat is especially sensitive to temperature that exceeds $32-33^{\circ} \mathrm{C}$ for any significant period, plants can be injured at seedling emergence, reproductive development, and stem elongation, heading and flowering by high temperature. Increased yields of crops had been a prime concern in breeding programmes. Wheat breeders all over the world have been utilizing the available genetic resources for this purpose. An understanding of the genetic factors that govern the yield components is necessary because breeding for yield depends largely upon genetic manipulation of the components along with yield. These characters are polygenic and exhibit additive and nonadditive genetic variation. Parents with significant GCA effects are useful for exploitation through conventional crossing programme and those with significant SCA effects are suitable for obtaining desirables transgressive segregants in wheat. Today, it has become amply clear that self-pollinated crops can exhibit similar extent of heterosis as in case of cross pollinated crops (Larik et al., 1995). In this context, the present study deals with such endeavor.

\section{Materials and Methods}

The experimental material for the present study comprised of ten genetically diverse wheat genotypes collected from All India Coordinated Wheat and Barley Improvement Project (AICW\&BIP), Rajasthan Agricultural Research Institute, Durgapura, Jaipur and their $45 \mathrm{~F}_{1}$ 's. Crosses were made among the ten barley genotypes namely; Raj 1482, Raj 3765, Raj 3077, Raj 3777, Raj MR-1, Raj 4238, Raj 4079, Raj 4120, DPW 621-50 and WH 1105 in half diallel fashion during rabi 2015-16 at Agronomy Farm, S.K.N. College of Agriculture, Jobner. Ten parents and their resulting $45 \mathrm{~F}_{1}$ 's were grown in a randomized block design with three replications under high temperature condition during rabi 201617 at Agronomy farm, S.K.N. College of Agriculture, Jobner. Sowing was done about 30 days later than normal date of sowing which created high temperature stress environment at post anthesis. The parents and $\mathrm{F}_{1}$ 's were grown in a plot of two rows of 2 meter length with row to row distance of 30 $\mathrm{cm}$ and plant to plant distance of $10 \mathrm{~cm}$. Ten 
competitive plants in parents and $\mathrm{F}_{1}$ 's were selected randomly for recording observations on thirteen characters namely, days to heading, grain filling duration, days to maturity, plant height $(\mathrm{cm})$, number of tillers per plant, flag leaf area $\left(\mathrm{cm}^{2}\right)$, number of grains per spike, peduncle length $(\mathrm{cm})$, spike length $(\mathrm{cm}), 1000$-grain weight $(\mathrm{g})$, biological yield per plant $(\mathrm{g})$, grain yield per plant $(\mathrm{g})$ and harvest index.

Analysis of variance for all the characters was done as suggested by Panse and Sukhatme (1985). The heterosis (H\%) and heterobeltiosis $(\mathrm{HB} \%)$ were estimated as deviation of $F_{1}$ value from the mid-parent and the better-parent values as suggested by Fonsecca and Patterson (1968), respectively.

\section{Results and Discussion}

The analysis of variance in heat stress environment revealed significant differences among parents for all the characters except days to heading, grai filling duration, peduncle length and 1000 grain weight. The $\mathrm{F}_{1}$ 's also showed significant differences for all the studied characters. The mean squares due to parents vs $F_{1}$ 's were found significant for most of the traits except grain filling duration, plant height, peduncle length and biological yield per plant. The parents vs $\mathrm{F}_{1}$ 's were found significant for almost all the traits, indicating the existence of heterosis.

This study may also help to identify the cross combination which are promising in conventional breeding programme. Mackey (1976) described genetic principles of expression of heterosis superior to the better parent, which may result from one or two of the following situations: (i) the accumulated action of favourable dominant or semidominant genes dispersed amongst two parents i.e. dominance; (ii) the complementary interaction of additive dominant on recessive genes at different loci i.e. non-allelic interaction or epistasis; (iii) favourable interaction between two alleles at the same locus i.e. intra locus or inter allelic interactions referred to as over dominance. It will be possible to recover homozygous lines as good as heterotic hybrids if either or both of the first two situations are cause heterosis, although the case with which such lines can be recovered will depend on linkage relationship of the genes involved and the ability to identify the recombinants as and when they arise. This will be particularly difficult with close linkage and when heterosis is expressed by a slight improvement in each of main yield components. If the heterosis is due to inter allelic interactions of dominant types, it is not possible to fix such heterosis in homozygous condition in subsequent generations. The commercial utilization of heterosis is regarded as magnificent implementation of genetics in the plant breeding. The magnitude of heterosis in a crop relies on its exploitation, utilization and practicability of hybrid seed production. The superiority of hybrids particularly over better parent (heterobeltiosis) is more important and useful in determining the feasibility of commercial exploitation of heterosis and also indicating the parental combinations capable of producing the highest level of transgressive seggregants.

In this study, as the parents are highly adapted varieties, heterosis over mid parent and over better parent have high practical significance. Investigation on degree of heterosis is, however, important as it may be of value in deciding the directions of future breeding programme. In the present investigations both heterosis and heterobeltiosis have been worked out. Higher grain yield is desirable, which is reflected by positive heterosis. The estimates of heterosis revealed that the crosses response to heterosis was differ in 
character to character as well as cross to cross in high temperature stress environment. The range of heterosis under high temperature stress environment varied from -4.99 (Raj $3765 \times$ WH 1105 ) to $12.12 \%$ (Raj 3777xRaj 4079) for days to heading; -19.47 (Raj $3077 x$ DPW 621-50) to $13.36 \%$ (Raj 4238xRaj 4079) for grain filling duration; 7.18 (Raj 3077xDPW 621-50) to $2.65 \%$ (Raj $3777 \times$ WH 1105) for days to maturity; -5.89 (Raj 3765xRaj 4079) to $8.47 \%$ (Raj 3077xWH 1105) for plant height; -13.58 (Raj $3777 x$ Raj 4238) to $26.95 \%$ (Raj 3765xRaj 3777) for number of tillers per plant; -18.96 (Raj 3077xWH 1105) to $19.84 \%$ (Raj 3777xRaj 4238) for flag leaf area; 19.31 (Raj $3777 x$ Raj 4238) to $21.78 \%$ (Raj MR-1xRaj 4079) for peduncle length; and -12.50 (Raj $3765 x$ Raj 4079) to $22.64 \%$ (Raj MR-1xRaj 4120) for spike length; -3.58 (Raj 3777xEaj 4120 ) to $24.46 \%$ (Raj MR-1xRaj 4120) for number of grains per spike; -7.39 (Raj $1482 \times W H 1105$ ) to $18.15 \%$ (Raj $3765 x$ Raj 4079) for 1000-grain weight; -2.36 (Raj 3077xRaj MR-1) to 30.49\% (Raj 3777xRaj 4120) for biological yield per plant; -0.02 (Raj MR-1xRaj 4238) to $21.11 \%$ (Raj MR1xRaj 4120) for grain yield per plant; -15.04 (Raj 3765xRaj 4238) to $28.22 \%$ (Raj 3077xRaj 4120) for harvest index.

Grain yield per plant is an important character for improvement of crop productivity. An overall study of grain yield per plant for heterosis revealed that out of 45 crosses, seventeen crosses in high temperature stress showed significant positive heterosis, whereas eleven crosses in high temperature stress showed significant positive heterobeltiosis, hence considered as desirable for this trait under high temperature stress.

Crosses Raj 3765xRaj 3777 followed by Raj 3765xRaj 4079 and Raj 3077xRaj 4079 had highest positive significant value of heterosis and Raj 3765xRaj 3777, Raj 1482xRaj 3777 and Raj 3765xRaj 4079 had highest positive significant value of heterobeltiosis, thus these crosses were observed most desirable cross combinations under high temperature stress environment (Table 1).

Maximum heterosis was observed as $34.22 \%$ (Raj 3765xRaj 3777) and maximum heterobeltiosis observed as $33.15 \%$ (Raj 3765xRaj 3777) in high temperature stress. Therefore, these crosses were observed more heterotic for grain yield per plant under high temperature stress environmental conditions.

On the basis of per se performance, heterosis and heterobeltiosis, the crosses Raj 3765xRaj 3777 and Raj 3765xRaj 4079 emerged as good crosses for grain yield per plant in high temperature stress environment. The superiority of hybrids particularly over better parent (heterobeltiosis) is more important and useful in determining the feasibility of commercial exploitation of heterosis and also indicating the parental combinations capable of producing the highest level of transgressive segregants.

Three best heterotic and heterobeltiotic crosses for different yield attributing traits has been presented in Table 2. An interesting relation between heterosis and heterobeltiosis for grain yield per plant and other yield attributing traits revealed that the crosses Raj 3765xRaj 3777, Raj 3077xRaj 4079 and Raj 3077xRaj 4079 in heat stress environment, exhibited most desirable heterosis and the crosses Raj 3765xRaj 3777, Raj 1482xRaj 3777 and Raj 3765xRaj 4079 possess high heterobeltiosis for four or more than four yield attributing traits. In present experiment high heterosis were observed for grain yield per plant as $34.22 \%$ followed by for Biological yield per plant $30.49 \%$, for Harvest index $28.22 \%$, for number of tillers per plant $26.95 \%$ and number of grains per spike $24364 \%$ under high temperature stress. 
Table.1 Estimates of heterosis $(\mathrm{H})$ and heterobeltiosis $(\mathrm{HB})$ for grain yield per plant for high temperature stress

\begin{tabular}{|c|c|c|}
\hline \multirow{2}{*}{$\begin{array}{c}\text { Character } \\
\text { Cross }\end{array}$} & \multicolumn{2}{|c|}{ Grain yield per plant (g) } \\
\hline & H & HB \\
\hline Raj 1482x Raj 3765 & $12.60 * *$ & $12.16^{*}$ \\
\hline Raj 1482x Raj 3077 & 2.41 & 1.95 \\
\hline Raj 1482x Raj 3777 & $22.07 * *$ & $20.62 * *$ \\
\hline Raj 1482x Raj MR-1 & 9.38 & 0.99 \\
\hline Raj 1482x Raj 4238 & $20.66 * *$ & $14.25 * *$ \\
\hline Raj 1482x Raj 4079 & $12.75 * *$ & 8.38 \\
\hline Raj 1482x Raj 4120 & 3.68 & 2.62 \\
\hline Raj 1482x DPW 621-50 & 2.11 & -7.22 \\
\hline Raj 1482x WH 1105 & 5.57 & 0.45 \\
\hline Raj 3765x Raj 3077 & $19.35 * *$ & $19.28 * *$ \\
\hline Raj 3765x Raj 3777 & $34.22 * *$ & $33.15 * *$ \\
\hline Raj 3765x Raj MR-1 & 0.40 & -6.97 \\
\hline Raj 3765x Raj 4238 & $10.85 *$ & 5.35 \\
\hline Raj 3765x Raj 4079 & $24.18 * *$ & $19.82 * *$ \\
\hline Raj 3765x Raj 4120 & $18.25 * *$ & $17.51 * *$ \\
\hline Raj 3765x DPW 621-50 & 5.49 & -3.81 \\
\hline Raj 3765x WH 1105 & 3.78 & -0.88 \\
\hline Raj 3077x Raj 3777 & -6.08 & -6.77 \\
\hline Raj 3077x Raj MR-1 & -6.48 & $-13.29 * *$ \\
\hline Raj 3077x Raj 4238 & -4.54 & -9.22 \\
\hline Raj 3077x Raj 4079 & $23.75 * *$ & $19.47 * *$ \\
\hline Raj 3077x Raj 4120 & 0.29 & -0.28 \\
\hline Raj 3077x DPW 621-50 & -7.08 & $-15.23 * *$ \\
\hline Raj 3077x WH 1105 & 1.64 & -2.88 \\
\hline Raj 3777x Raj MR-1 & 1.55 & -5.20 \\
\hline Raj 3777x Raj 4238 & 0.86 & -3.41 \\
\hline Raj 3777x Raj 4079 & $9.58^{*}$ & 6.56 \\
\hline Raj 3777x Raj 4120 & -8.83 & -8.98 \\
\hline Raj 3777x DPW 621-50 & 1.26 & -6.99 \\
\hline Raj 3777x WH 1105 & $17.92 * *$ & $13.49 * *$ \\
\hline Raj MR-1x Raj 4238 & -4.13 & -6.66 \\
\hline Raj MR-1x Raj 4079 & 2.31 & -1.90 \\
\hline Raj MR-1x Raj 4120 & $17.39 * *$ & 9.42 \\
\hline Raj MR-1x DPW 621-50 & 9.26 & 7.36 \\
\hline Raj MR-1x WH 1105 & 7.19 & 3.84 \\
\hline Raj 4238x Raj 4079 & $13.11 * *$ & $11.35^{*}$ \\
\hline Raj 4238x Raj 4120 & 3.54 & -1.01 \\
\hline Raj 4238x DPW 621-50 & $12.18 *$ & 7.39 \\
\hline Raj 4238x WH 1105 & 8.65 & 8.09 \\
\hline Raj 4079x Raj 4120 & $15.65 * *$ & $12.27 *$ \\
\hline Raj 4079x DPW 621-50 & $14.84 * *$ & 8.29 \\
\hline Raj 4079x WH 1105 & 2.33 & 1.25 \\
\hline Raj 4120x DPW 621-50 & -8.01 & $-15.63 * *$ \\
\hline Raj 4120x WH 1105 & 4.41 & 0.32 \\
\hline DPW 621-50x WH 1105 & -2.07 & -6.72 \\
\hline SE & 0.51 & 0.59 \\
\hline
\end{tabular}


Table. 2 Top three crosses for their heterosis and heterobeltiosis estimates in high temperature stress environment for different characters

\begin{tabular}{|c|c|c|}
\hline Characters & Heterosis & Heterobeltiosis \\
\hline \multirow{3}{*}{ Days to heading } & Raj 3765xWH 1105 & Raj 3765xWH 1105 \\
\hline & Raj MR-1xRaj 4120 & Raj 3077xRaj 4238 \\
\hline & Raj 3077xRaj 4238 & Raj 4238xRaj 4079 \\
\hline \multirow[t]{3}{*}{ Gain filling duration (days) } & Raj 4238xRaj 4079 & - \\
\hline & Raj 3777xWH 1105 & - \\
\hline & Raj MR-1xWH 1105 & - \\
\hline \multirow[t]{3}{*}{ Days to maturity } & Raj 3077xDPW 621-50 & Raj 3077xDPW 621-50 \\
\hline & Raj 3077xRaj 4238 & Raj 3765xRaj 4079 \\
\hline & Raj 3777xRaj MR-1 & Raj 3777xRaj MR-1 \\
\hline \multirow[t]{3}{*}{ Plant height (cm) } & Raj 3765xRaj 4079 & DPW 621-50xWH 1105 \\
\hline & Raj 3765xWH 1105 & Raj 4079xDPW 621-50 \\
\hline & - & Raj 3077xRaj MR-1 \\
\hline \multirow[t]{3}{*}{ Number of tillers per plant } & Raj 3765xRaj 3777 & Raj 3765xRaj 3777 \\
\hline & Raj 4079xDPW 621-50 & Raj 1482xRaj 3777 \\
\hline & Raj 3077xRaj 4079 & - \\
\hline \multirow[t]{3}{*}{ Flag leaf area $\left(\mathrm{cm}^{2}\right)$} & Raj 3777xRaj 4238 & - \\
\hline & Raj 3777xRaj 4120 & - \\
\hline & Raj 4120xDPW 621-50 & - \\
\hline \multirow[t]{3}{*}{ Peduncle length $(\mathrm{cm})$} & Raj MR-1xRaj 4079 & - \\
\hline & Raj 1482xRaj MR-1 & - \\
\hline & Raj 3765xRaj 4120 & - \\
\hline \multirow[t]{3}{*}{ Spike length (cm) } & Raj MR-1xRaj 4120 & Raj MR-1xRaj 4120 \\
\hline & Raj 3777xRaj 4238 & Raj 3765xRaj 3777 \\
\hline & Raj 3765xRaj 3777 & Raj 4079xRaj 4120 \\
\hline \multirow[t]{3}{*}{ Number of grains per spike } & Raj MR-1xRaj 4120 & Raj 3765xRaj 3777 \\
\hline & Raj 3765xRaj 3777 & Raj 1482xRaj 3765 \\
\hline & Raj 3777xRaj 4238 & Raj MR-1xRaj 4120 \\
\hline \multirow[t]{3}{*}{ 1000-grain Weight (g) } & Raj 3765xRaj 4079 & Raj 3765xRaj 4079 \\
\hline & Raj 3077xRaj 4079 & Raj 3765xRaj 4120 \\
\hline & Raj 3765xRaj 4120 & Raj 3077xRaj 4079 \\
\hline \multirow[t]{3}{*}{ Biological yield per plant (g) } & Raj 3765xRaj 4238 & Raj 3077xRaj 4079 \\
\hline & Raj 3077xRaj 4079 & Raj 3777xWH 1105 \\
\hline & Raj 3777xWH 1105 & Raj 3765xRaj 4238 \\
\hline \multirow[t]{3}{*}{ Grain yield per plant (g) } & Raj 3765xRaj 3777 & Raj 3765xRaj 3777 \\
\hline & Raj 3765xRaj 4079 & Raj 1482xRaj 3777 \\
\hline & Raj 3077xRaj 4079 & Raj 3765xRaj 4079 \\
\hline \multirow[t]{3}{*}{ Harvest index (\%) } & Raj 3077xRaj 4120 & Raj 1482xRaj 4238 \\
\hline & Raj 3077xRaj MR-1 & Raj 3077xRaj 4120 \\
\hline & Raj 3077xRaj 3777 & Raj 4238xRaj 4120 \\
\hline
\end{tabular}


Table.3 Crosses possessing with high heterosis $(\mathrm{H})$ and heterobeltiosis $(\mathrm{HB})$ for grain yield per plant $(\mathrm{g})$ along with desirable $(+)$ heterotic expression for other characters in high temperature stress environment

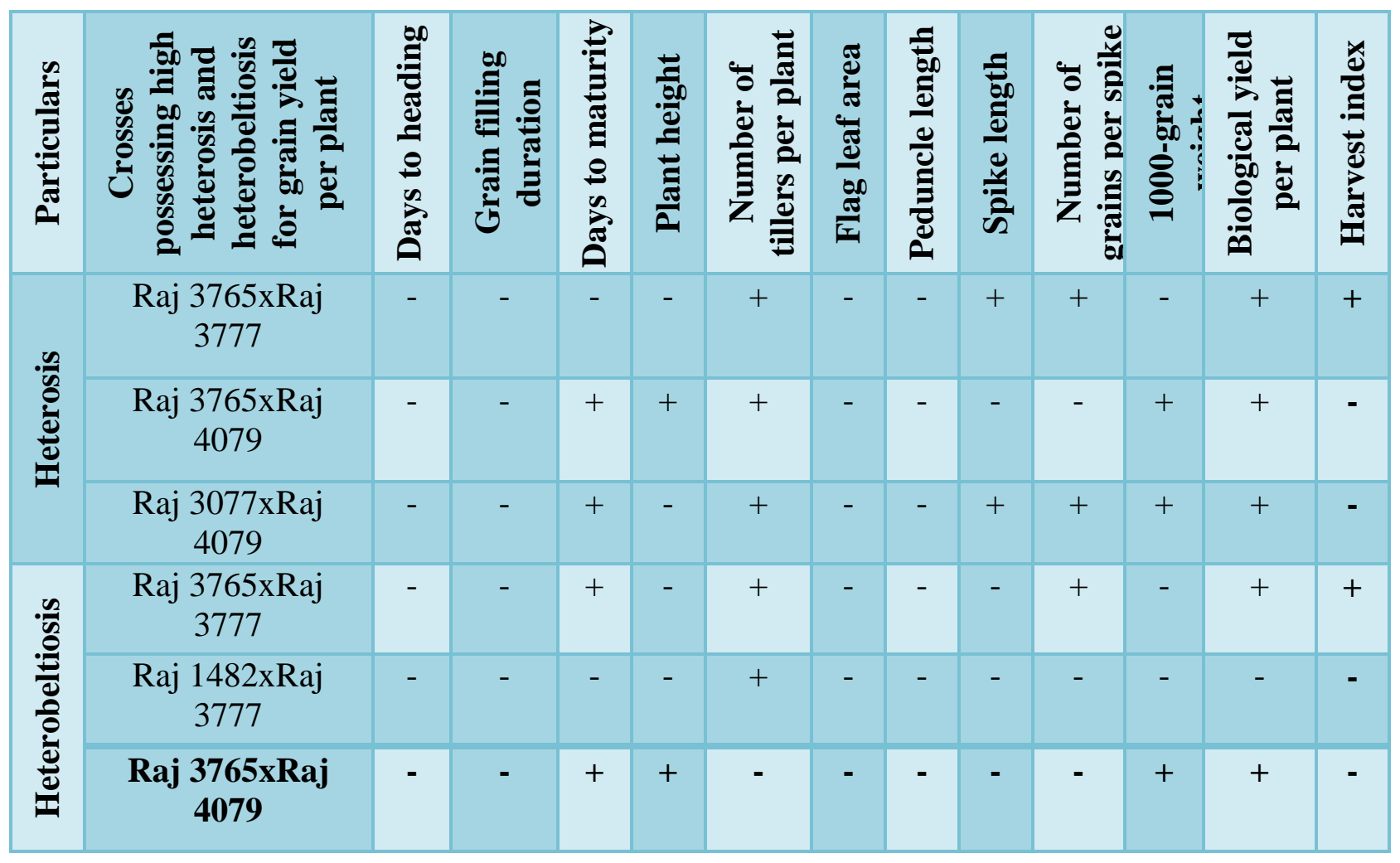

In present experiment, the parents, who showed desirable heterosis and heterobeltiosis for grain yield per plant, also exhibited desirable heterosis and heterobeltiosis at least for one or more yield attributing characters. Such as, heterosis for grain yield per plant was mainly contributed by days to maturity, number of tillers per plant, spike length, number of grains per spike and biological yield per plant; while heterobeltiosis by days to heading, biological yield and harvest index in both the environments.

Findings of this investigation supported the contentions of Grafius (1959), who suggested that there could be no separate gene system for yield per se as yield is an end product of the multiplicative interactions among its various contributing attributes.

Thus, heterobeltiosis for various yield contributing characters might be result in the expression of heterobeltiosis for grain yield. However, the crosses showing heterotic expression for grain yield per plant were not heterotic for all the characters. It was also noted that the expression of heterosis and heterobeltiosis was influenced by the environments for almost all the characters. This was because of significant $G \times E$ interaction. The results are in harmony with Joshi et al., (2003.b), Singh et al., (2004), Pancholi et al., (2012) and Raj and Kandalkar (2013).

It is concluded that the sufficient degree of heterosis and heterobeltiosis were observed for all the characters studied. The crosses Raj 3765xRaj 3777, Raj 3077xRaj 4079 and Raj 3077xRaj 4079 in heat stress environment, exhibited most desirable heterosis and the 
crosses Raj 3765xRaj 3777, Raj 1482xRaj 3777 and Raj 3765xRaj 4079 possess high heterobeltiosis for four or more than four yield attributing traits. Therefore, above crosses may be observed as promising types for tangible advancement in yield potential in barley under heat stress condition.

An overall evaluation of Heterosis for grain yield per plant revealed that the Maximum heterosis was observed as $34.22 \%$ (Raj 3765xRaj 3777) and maximum heterobeltiosis observed as 33.15\% (Raj 3765xRaj 3777) in high temperature stress. Therefore, these crosses were observed more heterotic for grain yield per plant under high temperature stress environmental conditions. The magnitude of Heterosis was observed for grain yield per plant as $34.22 \%$ followed by for Biological yield per plant $30.49 \%$, for Harvest index $28.22 \%$, for number of tillers per plant $26.95 \%$ and number of grains per spike $24364 \%$ under high temperature stress.

On the basis of per se performance, heterosis and heterobeltiosis, the crosses Raj 3765xRaj 3777 and Raj 3765xRaj 4079 emerged as good crosses for grain yield per plant in high temperature stress environment.

The present investigation reveals an ample scope for exploitation of hybrid vigour for commercial production as well as isolation of pure lines among the progenies of heterotic $F_{1}$ for tangible advancement of grain yield in wheat under high temperature stress environment.

\section{Acknowledgement}

The author is extremely acknowledged to the Department of Plant Breeding and Genetics, S.K.N. College of Agriculture Jobner and RARI, Durgapura, Jaipur for the material and other supports. They also acknowledge the unfailing cooperation and assistance of
Agronomy Farm, S.K.N. College of Agricuture, Jobner for providing the necessary facilities and field assistance for conducting experiment.

\section{References}

Anonymous. 2019. Commissionerate of Agriculture, Rajasthan, Jaipur. Pp: 1-8

Anonymous. 2019. United States Department of Agriculture. Foreign Agricultural Service. Production Supply and Distribution (PSD). Pp: 15

Fonseca, S. and Patterson, F.L. Hybrid vigour in a seven parental diallel cross in common winter wheat (Triticum aestivum L.). Crop Sci. 51(9): 623-626 (1968).

Grafius, J.E. Heterosis in barley. Agron. J., 51(9): 551-554 (1959).

Joshi, S.K., Sharma, S.N., Singhania, D.L. and Sain, R.S. 2003a. Genetic analysis of yield and its components traits in spring wheat. Acta Agronomica Hungarica, 51: 139-147.

Larik, A.S., Mahar, A.R. and Hafiz, H.M.I. 1995. Heterosis and combining abilityestimates in diallel crosses of six cultivars of spring wheat. Wheat Information Service, 80: 12-19.

Mackey, I. Genetic and Evolutionary Principles of Heterosis. In: Janossy, A. and Lupton, F.G.H. (Eds), Heterosis in Plant Breeding. Proc.VIII Congr. EUCARPIA Elsevier Scientific Pub. Co., Amsterdam. pp.17-33 (1976).

Pancholi, S.R., Sharma, S.N., Sharma, Y. and Maloo, S.R. 2012. Combining ability computation from diallel crosses comprising ten bread wheat cultivars. Crop Research, 43 (1, 2 \& 3): 131-141.

Panse, V.C. and Sukhatme, P.V. Statistical methods for agricultural workers Published by ICAR, New Delhi (1985).

Raj, P. and Kandalkar, V.S. 2013. Combining ability and heterosis analysis for grain 
yield and its components in wheat. Journal of Wheat Research, 5 (1): 4549.

Singh, H., Sharma, S.N. and Sain, R.S. 2004. Combining ability for some quantitative characters in hexaploid wheat (Triticum astivum L. em. Thell.).In: Proccedings of the $4^{\text {th }}$ International Crop Science Congress. Brisbane; Australia.

Singh, K., Sharma, S.N., Sharma, Y. and Tyagi, B.S. Combining ability for high temperature tolerance and yield contributing traits in bread wheat.J. Wheat Res. 4(1 29-37 (2012).

\section{How to cite this article:}

Guman Singh, Dhirendra Singh, D. K. Gothwal, Naresh Parashar and Ravi Kumar. 2020. Heterosis Studies in Bread Wheat (Triticum aestivium L.) under High Temperature Stress Environment. Int.J.Curr.Microbiol.App.Sci. 9(06): 2618-2626 doi: https://doi.org/10.20546/ijcmas.2020.906.318 